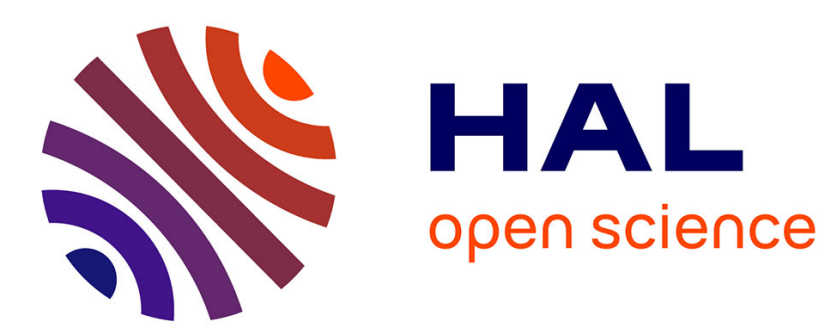

\title{
A small screen alternative to stone and bronze
}

Emma Hanna

\section{To cite this version:}

Emma Hanna. A small screen alternative to stone and bronze. European Journal of Cultural Studies, 2007, 10 (1), pp.89-111. 10.1177/1367549407072972 . hal-00571536

\section{HAL Id: hal-00571536 https://hal.science/hal-00571536}

Submitted on 1 Mar 2011

HAL is a multi-disciplinary open access archive for the deposit and dissemination of scientific research documents, whether they are published or not. The documents may come from teaching and research institutions in France or abroad, or from public or private research centers.
L'archive ouverte pluridisciplinaire HAL, est destinée au dépôt et à la diffusion de documents scientifiques de niveau recherche, publiés ou non, émanant des établissements d'enseignement et de recherche français ou étrangers, des laboratoires publics ou privés. 
Copyright (C) 2007 SAGE Publications London, Los Angeles, New Delhi and Singapore Vol $10(1) 89-111 ; 1367-5494$ DOI: $10.1177 / 1367549407072972$ WWw.sagepublications.com

\title{
A small screen alternative to stone and bronze The Great War series and British television
}

\section{Emma Hanna}

University of Greenwich

\begin{abstract}
This article examines the first major British television series about the First World War, The Great War (BBC, 1964), in terms of its cultural, historical and aesthetic significance. As a central component of the BBC's 50th anniversary commemorative programme to mark the outbreak of war, the series was a major media event - a small-screen memorial cast in sounds and images instead of stone and bronze. This article looks at how the British television audience responded to this form of on-screen commemoration. Material for this article was derived from the series' extensive production records housed in the BBC Written

Archives Centre at Caversham, Berkshire. This was supplemented by, among other sources, material from interviews and correspondence with several surviving members of the production team. This allows a broader understanding of the motivations of those involved in the production of a groundbreaking historical series, while acknowledging the wide-ranging nature of its audience.

KEYWORDS commemoration, culture, First World War, remembrance, representation, television
\end{abstract}

In Great Britain the First World War has been commemorated and memorialized more than any other conflict. In the years after 1918, individual and family experiences were collectivized in virtually every city, town and village with the building of thousands of memorials to the dead. The loss of more than 750,000 of its sons had a profound effect on Britain's national consciousness, and this affected the way in which the war has been historicized (Robb, 2002).

The study of memory was first approached by the French sociologist Maurice Halbwachs in the 1920s (see Halbwachs, 1980[1950]). Halbwachs followed Emile Durkheim's (1965[1912]) notion of collective conscience - the contention that all acts of memory are social and that to remember 
is to act as part of the collective - but his insights were largely forgotten until the growth of interest in memory studies in the 1980s and 1990s. It was during this period that the ways in which the First World War has been remembered emerged as a significant historiographical issue. Researchers have concentrated so far on the study of commemorative sites and rituals, but it is time to recognize that, in contemporary British culture, these formal modes of commemoration represent a diminishing part of the wider public's perception of the First (and Second) World War.

In Britain since the 1960 s television has been the most influential medium of popular culture. Many historians now recognize that any cultural history of British society in the years after the Second World War cannot dismiss television output as a primary source which can tell us a great deal about the society for which it was made (Marwick, 2001; Tosh, 2006). Indeed, the media are such an all-pervasive part of contemporary life that any history of Britain post- 1945 would be wholly incomplete without a discussion of its role in modern society (Cannadine, 2004). After more than four decades of public broadcasting, it is time for historians to recognize that it is their business to understand and analyse television documentaries as influential texts of 'public history', a form of popular history designed to be consumed by a mass audience as opposed to academic history written for publication in specialist journals and monographs. Historians must learn to understand and appreciate the aesthetic elements of history on television, and the effect of those techniques on viewers' historical imagination.

This article will show that a study of the ways in which the First World War has been remembered in contemporary Britain needs to examine British television documentaries in terms of their cultural, historical and aesthetic significance. As the 90th anniversary of the end of the First World War approaches, there can be no better time to open up a field of research into how the most powerful broadcast medium of our time has communicated ideas about the conflict to British viewers.

As a medium designed for mass consumption, television has always had to communicate ideas that resonate with all participants (Sorlin, 1994). Therefore, British documentaries about the First World War have utilized the language and imagery of remembrance rituals that were established in the immediate postwar period by resonating with the elements of commemoration: the grief and consolation which lie at the heart of Britain's memory of 1914-18. The remembrance rituals and signifying practices of post-1918 Britain were framed in traditional language which was understood via commonly shared images and ideas derived from classical, romantic and Christian sources, where the bereaved found the languages which enabled them to mourn (Winter, 1995). The ironies underlined by Paul Fussell's The Great War and Modern Memory (1975) - that a new language emerged from the conflict to assist in contemporary understanding of the oddities, cruelties and enormities of collective violence - could 
shock, stimulate or delight but could not heal, and healing is what was (and perhaps still is) needed to help British society come to terms with the aftermath of 1914-18 (Winter and Prost, 2005).

This article examines the first major British television series about the First World War, the 26-part series The Great War (BBC, 1964), in terms of its cultural significance. The series was the most monumental of monuments: the first small-screen memorial to the British sacrifices of 1914-18. Made in a format fit for a new age in television, the series established a new benchmark for history programmes with its technological advances, such as the sweeping musical score, veteran interviews and archive images treated to look like contemporary newsreel. The Great $W$ ar also showed how a large television historical documentary series could be made to such a high standard as to establish television in Britain as a respectable format for history (Badsey, 2002). The current affairs-style approach pioneered by the series was widely reproduced, most prominently by a Second World War 26-part series The World at War (ITV, 1974), which was listed recently among a list of 24 television programmes which changed the face of British television. The $W_{\text {orld }}$ at $W$ ar producer Jeremy Isaacs, who later became the founding chief executive of Channel 4, acknowledged that it was The Great $W$ ar that showed what was possible in modern history documentaries (Isaacs, 2003).

The series still holds the record for being the longest-running television documentary about war, distilling 1561 days of 1914-18, which involved 26 nations and 65 million combatants in 16 theatres of war, into 26 episodes over 17 screen hours. The Great War also broke new boundaries with its generous budget, the voluminous amount of archive footage that it sourced from around the world, and the number of people involved in its production. Sixty full-time staff interviewed more than 1200 people from six different countries, helped by 70 organizations from around the world; the final cost of the project was in the region of $£ 250,000$, approximately one-third of the money required to produce a fictional film series (Gruner, 1964). The BBC's grand narrative of 1914-18 was hailed by the Sunday Times as 'The intelligent man's guide to Armageddon' (Wiggin, 1964: 32).

Moreover, The Great War showed that television was a suitable platform for the purpose of public remembrance, and the series laid the foundations for the powerful self-generative force of televisual commemoration. It was the first series to show that historical documentaries could become media events, and their narration would be placed in competition with the writing of history in defining the contents of collective memory (Dayan and Katz, 1992). As a central component of the BBC's 50th anniversary commemorative programme to mark the outbreak of war in 1914, The Great $W$ ar was a major media event. The series was seen by approximately one-fifth of British adults: a mean audience share of 16.5 percent with an average of 8,167,500 viewers per episode, as many as the most popular BBC prime-time programmes of the period such as Z-Cars 
(1962), The Dick Emery Show (1963), The Benny Hill Show (1964) and The Likely Lads (1965). ${ }^{1}$ During the 50th anniversary period interest in the war was already high, and it was still an event in which families felt some involvement. Significant parts of the audience watched film from the First World War as if it were news footage of an event in which they were closely involved, and the very existence of the quantity and quality of footage used by The Great War served to underline the importance of the series as a national memorial to the conflict (Todman, 2002).

This article adds to existing scholarship, and based on substantial research, it will introduce new evidence which allows a more detailed examination of the motives of the producer Tony Essex, the driving force behind the programme's design. The series was Essex's televisual memorial to the dead of the First World War, and this article will look at how the British television audience responded to this form of on-screen commemoration. It will conclude by explaining why The Great War failed to transcend pre-existing representations of the First World War and its place in British cultural memory. The material for this article was derived from the series' extensive production records housed in the BBC Written Archives Centre at Caversham, Berkshire. This was supplemented by, among other sources, material from interviews and correspondence with several surviving members of the production team. This will allow a broader understanding of the motivations of those involved in the production of a groundbreaking historical series, while acknowledging the wide-ranging nature of its audience.

\section{The First World War and British culture}

Although there were many Colenso and Mafeking Streets built after the Boer War (1899-1902), the public organization of private grief via the erection of thousands of war memorials after 1918 meant that death became synonymous with Britain's public memory of the First World War. In a similar way to calvaries in Catholic countries, the war memorial became the touchstone of things that were held in common by Britons, and Remembrance Day was for decades the moment at which people and nation fused (Smith, 1995). The unprecedented scale of loss in the First World War led to the first comprehensive commemoration of every man that died, whether he was an officer or private soldier, volunteer or conscript. Monuments for the dead appeared in every town, village and city, in schools, factories and town halls. It became almost impossible for anyone to think or write about the war without the use of rhetoric thought to reflect the enormity of the conflagration and the number of lives lost (Smith, 1995). In this way, the fighting of 1914-18 continues to cast a long shadow over British culture in the 21st century (Bond, 2002).

The accepted language of remembrance enshrined the experience of the war. By removing it from social and political debate and elevating it to a 
level of spiritual significance, the conflict's memory for peacetime British society was of a special and sacred quality. The mass of British society was discouraged from entering into a political discussion of the war's causes and consequences through annual acts of remembrance underlined by Kipling's 'Lest we forget' (Reimann, 1998). These remembrance rituals were designed to be self-generating. For example, in November 1921, the British Legion established the sale of red Flanders poppies, an annual act of individual remembrance which was cemented within ceremonial rituals by the laying of poppy wreaths and the cascade of a million poppies fluttering on the assembly at every British Legion Festival of Remembrance since 1927. The service of remembrance, held at the Cenotaph in Whitehall, was broadcast on BBC radio every year from 1923, and it was televised from 1937 with a six-year hiatus during the Second World War.

National differences in First World War memory are pronounced. In Britain there is no sense of the war as a British victory, and poets and novelists have been much more influential in shaping the British discursive field of remembrance than has been seen in other combatant countries. In France the centralized educational system creates a space for historians to contribute directly to a national pedagogic project through centrally-controlled textbooks, and studying the First World War is an integral part of preparing students for active citizenship (Winter and Prost, 2005). The study of remembering the conflict in Germany is still in its early phases. A greater number of academics have turned their attention to $1914-18$ in more recent times, which has developed significantly our understanding of German culture during and after the war (Stibbe, 2001; Verhey, 2000; Winter, 1995; Winter and Robert, 1997). Nevertheless, although British historians have produced an enormous body of scholarly and detailed work, this has had a negligible effect on the way in which the majority of the nation thinks about the war. The assumption that the First World War can be understood through its literature has proved particularly persistent.

The British education system has played a major role in buttressing the popular misconception that the 'truth' of 1914-18 can be found in its literature, ever since Wilfred Owen's poetry appeared on A-level English literature syllabuses in 1960. Indeed, the cornerstones of war myths had been cemented already by a flood of books about the war from the late 1920s, including Siegfried Sassoon's Memoirs of a Fox-Hunting Man (1928), Edmund Blunden's Undertones of War (1928), Robert Graves' Goodbye to All That (1929), Frederick Manning's Her Privates We (1930) and Cecil Lewis' Sagittarius Rising (1936). After the Second World War there was a resurgence of interest seen in a 'reflowering' of the literature of disillusionment and in the cynical anti-heroic representations of the earlier conflict. Alan Clark's The Donkeys (1961), Barbara Tuchman's Guns of August (1962) and A.J.P. Taylor's The First World War (1963) reinforced the negative images of the war as a cruel and futile slaughter. 
Anthony Burgess's novel The Wanting Seed (1962) even used the First World War as a blueprint for mass slaughter in a future genocide, and the film King and Country (Joseph Losey, 1964) was a sympathetic tale of a First World War private shot for desertion. On 19 March 1963, a musical play Oh, What a Lovely $W$ ar! was performed by the Theatre Workshop at the Theatre Royal, Stratford East, London. The production, largely organized by the left-wing director Joan Littlewood, was a scathing attack on Britain's involvement in the war, underlining the ignorance and petty rivalries of European royal families and the British high command as well as the jingoistic masses who cheered for a war that destroyed approximately 20 million lives.

In British memory the First World War is not only a for gotten victory but a national tragedy, a story that can be told again and again where neither the plot nor the symbols which define the period can be changed (Sorlin, 1999). Britain's war effort affected every part of British society and a persistent undercurrent of emotional involvement has continued to pull Britons back to the war, to revisit, reconsider and refight its battles, whether or not they experienced them first-hand (Todman, 2005). The overriding influence of the First World War in British culture is mourning, and Britain's memory of the conflict will continue to provoke emotions such as sorrow and bewilderment. It is not that there is a lack of facts and statistics - they are available in substantial measure - but in any public representation of the war, feelings rise to the surface first (Kavanagh, 1994). It is for this reason that the First World War has continued to find a place in the broadcast schedules to the present day, especially in the months of July and November. For example, the recent 90 th anniversary of the Battle of the Somme was remembered by several single-episode programmes including The Somme (Channel 4, 2005) and The Somme: From Defeat to Victory (BBC, 2006). However, the first televisual memorial made to commemorate the battle, Battle of the Somme, was made by the $\mathrm{BBC}$ in 1976 and repeated for the 70th anniversary in 1986. Channel 4 paid its own on-screen tribute in 1985 to the men who fought at the Somme in Lions Led by Donkeys, and commemorative programming continued throughout the 1990s, for example $A$ Game of Ghosts (BBC, 1991) and Shot at Dawn (Carlton, 1998).

The 50th anniversary commemorations in the 1960s had a profound commercial and psychological significance, a reminder that the First World War was still an unexorcised and barely-healed national trauma (Danchev, 1991). The feeling that the national public broadcaster should produce a series to mark the beginning of the conflict had been mooted in 1960 by Paul Johnson, a journalist on the New Statesman, but discussions about such a project were suspended during the reorganization of the BBC 'Talks' department in $1961 .^{2}$ In the meantime, prior to the anniversary of the outbreak of war, well-known wartime veterans such as Vera Brittain enquired about the BBC's plans. ${ }^{3}$ The need for the BBC to produce some 
sort of televisual contribution to the 50th anniversary was resolved at the end of August 1963 when Alasdair Milne, head of the BBC's Tonight productions, had seen Victory at Sea in America (Brown, 2003). On Milne's suggestion, the series that was to become known as The Great $W$ ar was commissioned as a central component of the BBC's commemorative programme alongside The Life of Wilfred Owen, Britten's $W$ ar Requiem and Songs of the Trenches (all 1964).

The BBC had seen already that history programmes were popular throughout the 1950 s and early 1960s. Epic history documentaries such as Victory at Sea (BBC, 1952), War in the Air (BBC, 1954) and Valiant Years (BBC, 1961) had paved the way for the use of stirring musical scores, eloquent narration and dramatic archive footage. Lieutenant-General Sir Brian Horrocks' Men in Battle (BBC, 1956), Epic Battles (BBC, 1958) and Battle in Space (BBC, 1958) attracted audiences of more than six million viewers as did anything by A.J.P. Taylor. The expansion of higher education by the Labour governments of the 1960 s created more historians as well as a more educated audience for published works of history. However, programmes broadcast on the developing television medium could reach millions of people who did not need a long academic apprenticeship to understand the war. This period marks a historiographical change; a new vision of the Great War was made possible by television, inevitably marked by the faces of individual men and women who had participated (Winter and Prost, 2005).

Indeed, by the early 1960 s the number of men and women with direct experience of the First World War began to decrease at a sharper rate. Representations of the war on television reflected the developments of works about it in print by mining the relatively vast but diminishing seams of memory of the British 'Tommy' at war. The Great War was the first series to feature veterans of the conflict speaking of their own war experiences, slotted into the series' narrative, after a public appeal in the national press for them to come forward. ${ }^{4}$ Producer Tony Essex was particularly keen to present the average fighting man's experience, to enable his team

to form an accurate picture of what the Great War was like. By reading the 50,000 letters, stories, and articles etc submitted our writers have been able to fill in the blanks which most histories contain - i.e. the human side. (Letter from Tony Essex to Mr W. Holvey of Bristol, 17 August 1964, Imperial War Museum Department of Documents, Volume HOA-HOY 'The Great War')

Most of the veterans who were interviewed for the series were men from the ranks, but they did include well-known personalities such as Charles Carrington, author of $A$ Subaltern's War (1929) and Soldier from the Wars Returning (1965), who had served as a British officer during the war. Other recognizable veterans interviewed for the series included Cecil Lewis, former Royal Flying Corps pilot and author of Sagittarius Rising, 
Henry Williamson, former infantry officer and author of the Chronicle of Ancient Sunlight series (1951-69) and Edmund Blunden, former infantry officer and author of Undertones of $W a r .{ }^{5}$ The chosen testimonies were recorded at the BBC's Ealing Studios in spring 1964. The Great War's eyewitness researcher Julia Cave recalled that the production team were well aware that they were making a very important piece of history. She recalled the mood of the staff, that: 'It was unlikely that these people would be interviewed again, and that [The Great $W$ ar $]$ was in a sense a historical record ... We were recording people for history. ${ }^{16}$

\section{Production}

The driving force behind the series was Tony Essex, a born romantic as well as an intelligent, well-read man, who supervised well-researched and tough-minded scripts (Ramsden, 2002). He was fully aware that 'a subject like the First World War would be wasted unless it was dealt with on a massive, thought-provoking, and moving scale. I wanted the series to be the biggest thing in the world' (Howarth, 1965: 8). In this way Essex continued the trend for histories of the First World War whose scale corresponded with the enormity of the events that they portrayed. Wartime artistic works had long sought to achieve parallels with the war's colossal presence: paintings such as John Singer Sergeant's Gassed (1919) and Percy Wyndham Lewis's A Battery Shelled (1919) were large in scale, and John Foulds' now forgotten World Requiem (1918-21) was a huge musical event in 20 movements which took 1200 singers and musicians two hours to perform. Published works had long measured the monumentality of the war's history by their sheer size, and newspapers such as The Times and the Manchester Guardian published lengthy serialized histories of the conflict (Hynes, 1990). Essex and his co-producer Gordon Watkins knew that the series had to be watchable and had to be a good story. Both men were trained journalists, and they knew that their history of the war had to have popular appeal as well as being historically rigorous. Essex believed that they were

telling a story as great as that of the Bible, in its way, and clarity and understanding are far more important than technical flair. If people can follow and understand, our task will be done. (BBC WAC T32/1152/1, Tony Essex to Gordon Watkins, 30 January 1964)

The best piece of film to demonstrate the series' aesthetic design is the opening title sequence. On a practical level the sequence separated its content from preceding programmes, and signalled its seriousness as a piece of national history. On a more critical level, it is an elegy and an overture which provide a dramatic exposition of thematic development, underlining that the series is an act of public memorialization. History on television always has had dramatic aspirations. Even A.J.P. Taylor's 
The First World War lecture series contained moving images from film archives, but The Great War's stylistic features included uneven narration, peaks and troughs at the beginning and end, and structural features to denote stasis and action in war, supported by crescendi in other codes such as music and cutting. All were used to stunning effect by Essex with particular emphasis on more tragic visual images. The film montage contains just three dramatic photographs from the Western Front - a silhouetted soldier (Figure 1), a single staring soldier (Figure 2), and a uniformed skeleton-corpse (Figure 3) - but the accelerating rostrum camera movements create an overall impression of a collage of many more.

Wilfred Joseph's score, which was written for the series, paces the quickening camera movements downwards and sideways. This creates a

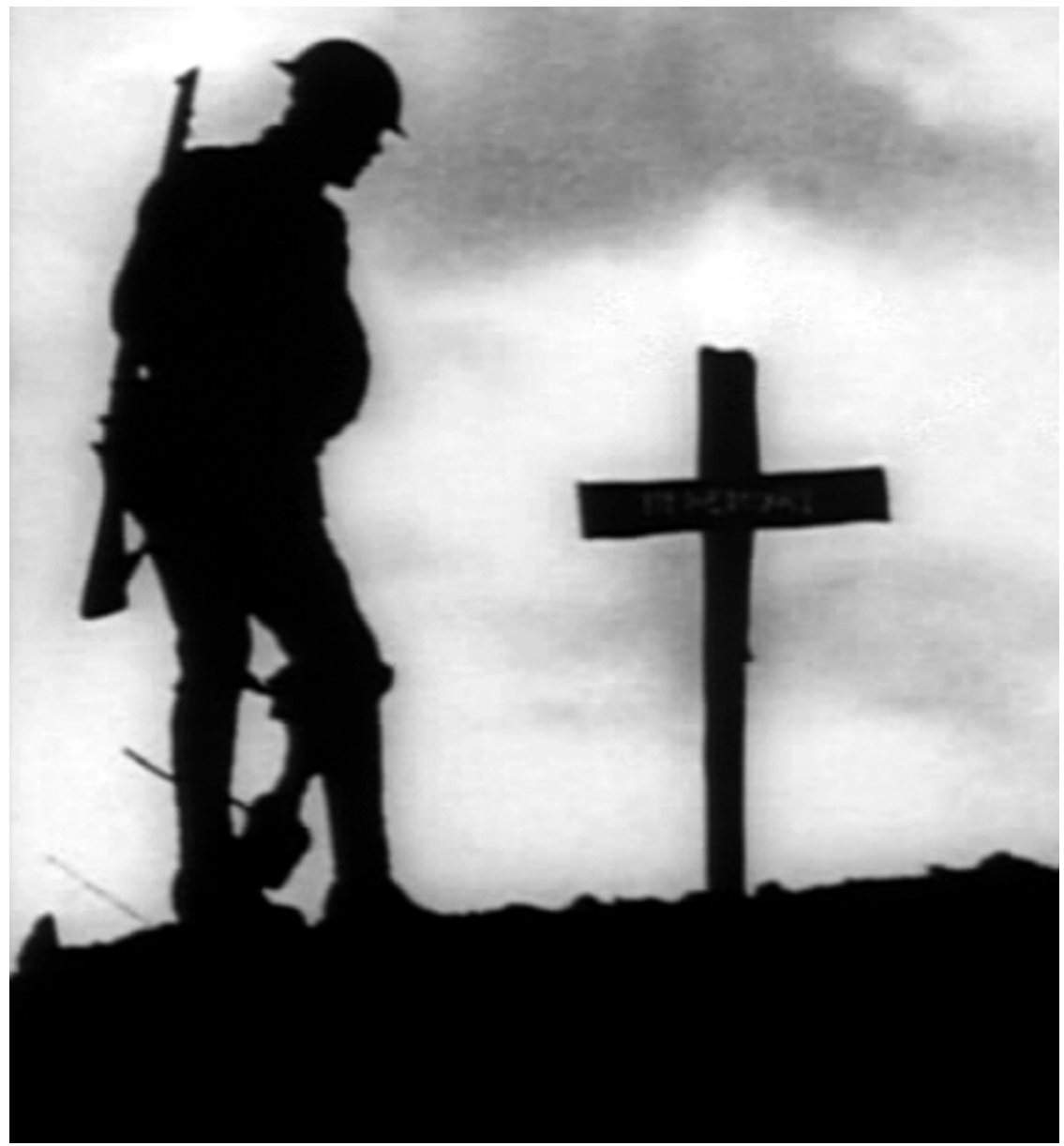

Figure 1 The 'Silhouetted Soldier' in The Great War opening sequence (reproduced with kind permission of the $B B C$ ) 


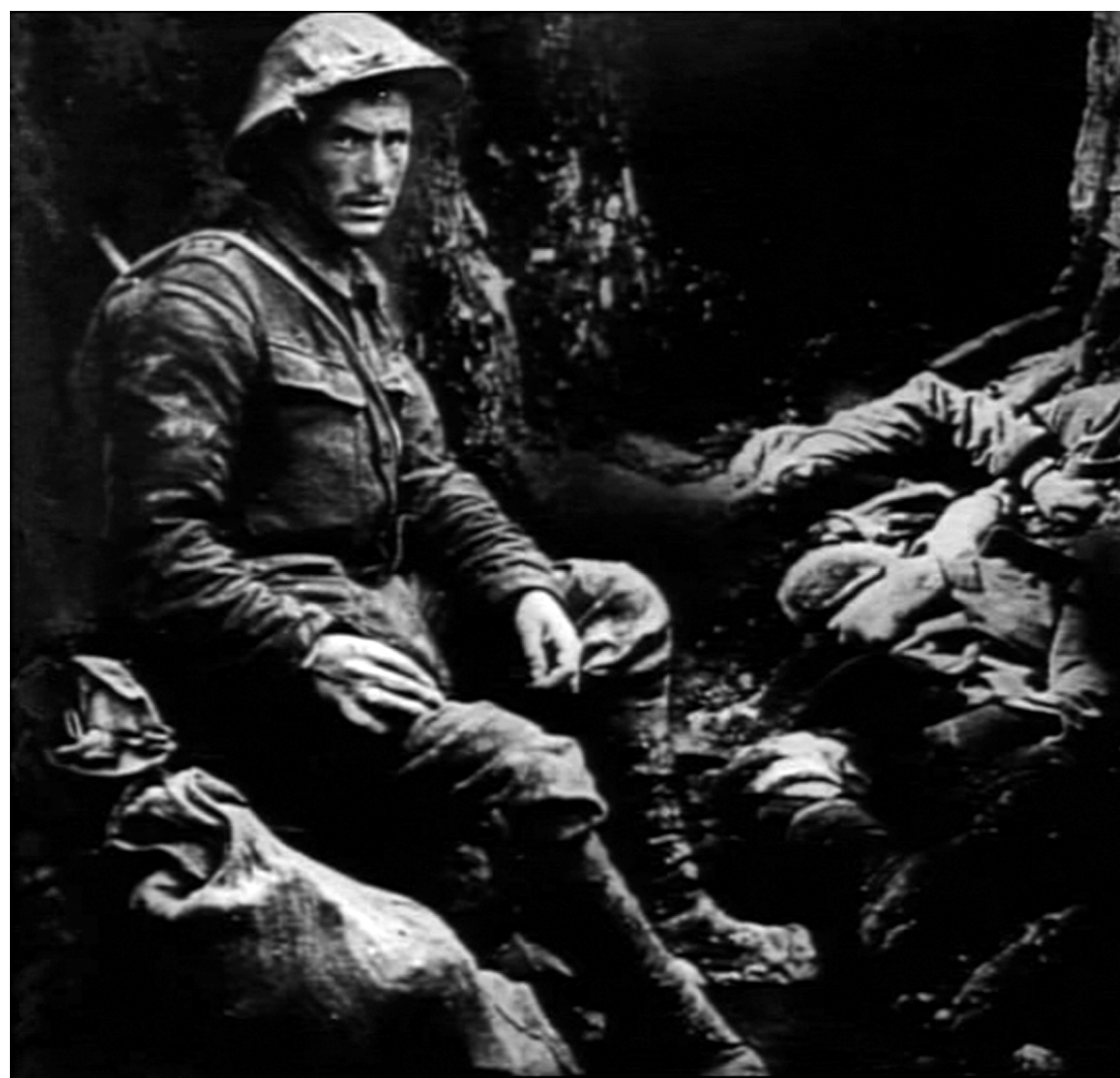

Figure 2 'The most famous unknown soldier in the world' - The Great War opening scene (reproduced with kind permission of the BBC)

freefalling effect as the viewer is dragged down through the horrifying depths of mud, confusion and despair (McArthur, 1978). This sequence was clearly designed to evoke the disorientation and horror embedded in the popular memory of the Western Front; muddy trenches, dashed hopes, death and decay. This sequence could be interpreted also as the emotional wasteland of an age living in the shadow of two world wars, as well as the post-atomic landscape of the early 1960s, but above all it is the visual recipe for the $W$ ar Imagined (Hynes, 1990).

It was the intention of those involved with the series that The Great War should capture the imagination of its viewing audience. The controller of BBC2, Donald Baverstock, was particularly keen that each programme should have 'moments of high television imagination', which Essex's coproducer Watkins took to mean 'moments that depend on sheer productive inventiveness'. ${ }^{7}$ Unlike any subsequent major documentary made in Britain, such as ITV's World at War (1974), Essex had control over 


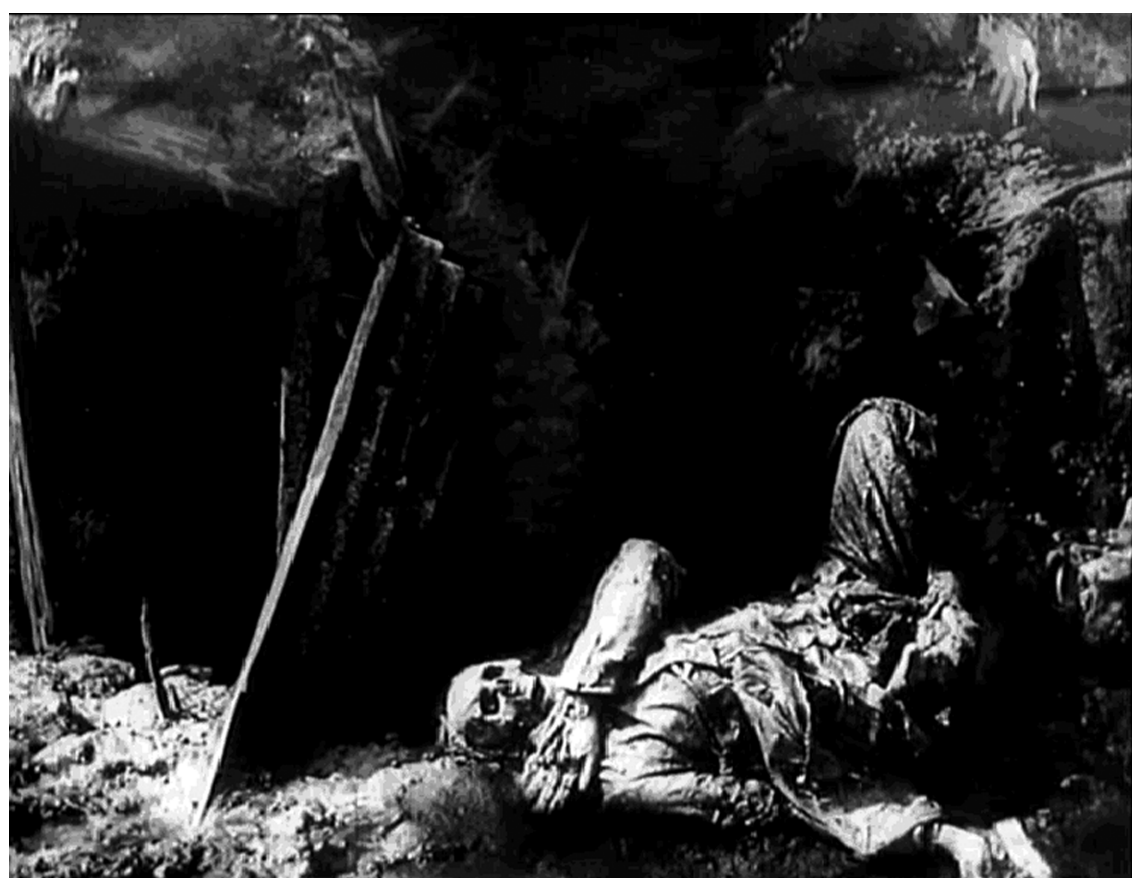

Figure 3 The uniformed skeleton-corpse in The Great War opening scene (reproduced with kind permission of the BBC)

every aspect of the series, including the design of the opening sequence, which he planned with great detail and imagination. ${ }^{8}$ In his directions to Malcolm Arnold, conductor of the BBC Northern Symphony Orchestra who performed the series title theme, Essex requested that 'a sombre building of tension' should be portrayed by the rising timpani strokes during the close-up 'of [a] rough wooden cross against the sombre sky' that is inscribed 'In Memory'. He then instructs that:

A helmeted soldier stands silently looking down at the cross. Both the cross and the soldier are silhouetted against a heavy sky. They stand on a hill, which too is black against the sky.

The timpani repeat the original stoke pattern twice 'with growing tension', and the script instructs that the camera begins

tilting down into almost blackness, (like Alice falling down the rabbit-hole to wonderland - only this time it's to horror).

As the music is sizzling and growing in stridency and volume with tremendous passion ... Great climatic crash of full orchestra, gong, the works!

The camera suddenly ends on the bottom of a trench where lies a ghastly uniformed shattered skeleton. As the music once again swells, strong, melodic, passionate, tragic ... 
Pan across derelict trench to another part where two dead bodies lie. Over them tired, exhausted, with uncomprehending eyes a British soldier leans against the trench wall. He looks at camera with a strange tired appeal. All the while track very slowly in to the TIRED FACE AND EYES OF THE soldier. (BBC WAC T32/1139/1 'Music and Visuals Script', Tony Essex to Malcolm Arnold, undated)

This is the final version that was used to introduce each of the 26 episodes. Earlier drafts for the title sequence in the $\mathrm{BBC}$ archives show the development of ideas that Essex wanted to convey about the conflict. As Essex's plans stood in November 1963, the opening scene featured a foggy reconstructed battlefield redolent of Lewis Milestone's film All Quiet on the Western Front (1930):

as if we are peering through the murk into the past... out of the fog looms simple dark shapes, a fallen helmet, a curl of broken barbed wire, a smashed gun-carriage wheel, a broken tree, and, finally, after the suggestion of a dead soldier's face, the body's arm looms into frame. (BBC WAC T32/1139/1 'Music and Visuals Script', Tony Essex to Malcolm Arnold, undated)

As the shell exploded and the smoke cleared, Essex directed that:

we dissolve into a desolate battle scene, over which, in silhouette on the left of frame, a figure of Grief stands in utter dejection. It should be a powerfully tragic pose ... As this title ends, the battlefield scene fades, leaving only a cloudy, hazy image, and the statue of Grief becomes lit. We begin to track into big close-up of the tragic face of the statue. (BBC WAC T32/1139/1 'Design Requirements', to Planning Manager, 19 November 1963)

Essex was happy to draw on the war's artistic legacy because he understood that the majority of people were familiar with the war through its most well-known poetry. Indeed, buried in the BBC's archive is proof that Essex wanted the opening sequence to include a reading of a poem to be specially written for the series by Siegfried Sassoon. In November 1963, Essex included in his design requirements that

[As the opening titles are rolling] one 6-line verse of a 26 -verse poem specially written for the series by Siegfried Sassoon is read. This starts off with words to the effect -

'I saw a million men ... etc.

(the middle lines change from week to week and set the theme for the particular programme being introduced, and the last line had words to the effect)...

'and they went singing to their death'. (BBC WAC T32/1139/1 'Design Requirements', to Planning Manager, 19 November 1963)

Sassoon did not write a poem for the series, and there is no written evidence to suggest that he was even aware of Essex's plans. It is highly unlikely that Sassoon would have agreed to be involved with the series as he disliked being remembered as a war poet, particularly after his conversion 
to Catholicism in $1957 .{ }^{9}$ The Great War's co-principal scriptwriter, military historian Correlli Barnett, believes that it is most likely that Essex intended to secure Sassoon's services for the opening sequence as a unique selling point. ${ }^{10}$ Nevertheless, it is significant that a poet who already had exerted a disproportionate influence on Britain's national memory of the war would be involved in a production of this type. These early drafts for the opening titles, which remained undiscovered in the BBC archives until recently, show that Essex's conscious and unconscious decisions led him to encode the titles as a montage of images that resonated with ideas about the war already embedded in British modern memory. The progression of Essex's ideas for the series clearly indicates that he designed the series as a national televisual memorial to a most tragic period in British history.

The single British soldier that challenged the viewer to meet his gaze at the start of every episode soon became an iconic image and one of the most memorable visuals from the series. In 1965 Essex described him as 'the most famous unknown soldier in the world' (1965: 51). It is well known that the picture of the soldier was taken from an Imperial War Museum photograph, numbered Q1 in its highly valued 'Q' series of 115,000 First World War images, which depicts him sitting with his more cheerful comrades in a trench before the attack on the Somme on 1 July 1916 (Figure 4).

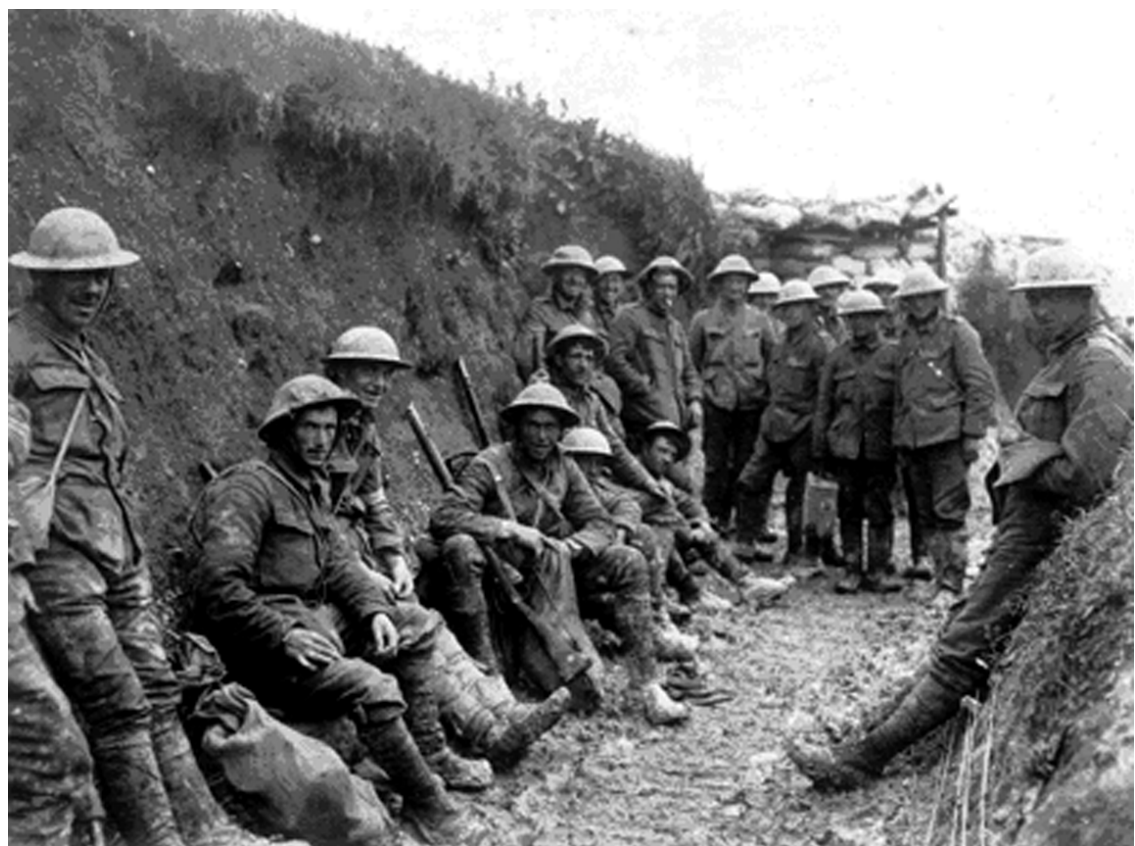

Figure 4 The original Imperial War Museum photograph (Q1) (reproduced with kind permission of the Imperial War Museum) 
Essex freely admitted that they had made a composite image, writing that 'it was done to suit our title sequence"11 and that 'every part of the composite picture is made up of actual photographs?. ${ }^{12}$ He had deliberately moulded the images to form a memorial in that the opening sequence would show the steps back in memory:

The opening sequence was designed to take us back in time, from the cross, which could be any memorial any time, via the survivor standing over the grave, down to the long dead skeleton, over to the recently dead in the trench and across to the 'not yet dead' soldier with the tragic face at the end of the sequence. To achieve this simple thought, the 'not yet dead' soldier has indeed been taken from another picture and placed in this more suitable setting ... The titles and their background serve one purpose, the body of the film another. (BBC WAC T32/1, 145/4 Tony Essex to Redmayne, 22 December 1964; emphasis in original)

This did not elude some sharp-eyed viewers, who wrote to the BBC informing them they would find the correct picture, without the corpses, on page 99 of $T$ The First $W_{\text {orld }} W$ ar (Taylor, 1963). After the series was broadcast there was a national appeal to identify the new 'Unknown Warrior' who quickly became a symbol for everyone's lost male relative. One viewer wrote in to say that his eldest brother, who was killed in the war during 1918, was 'the double of this soldier even to the index finger and thumb held in the left hand, this is an idiosyncrasy of our male family?. ${ }^{13}$ At the time he was named as Private Joseph Bailey of the 12th Battalion Yorkshire and Lancashire Regiment, who was killed in action just hours after the photograph was taken. Subsequent research, however, revealed that the soldier in the photograph belonged to an Irish regiment, and that his name was almost certainly not Joseph Bailey.

Another new discovery in the archives was that, as the staring soldier's photograph was adjusted, the image of the silhouetted soldier (Figure 1) used in the opening sequence was staged by the official war photographer Lieutenant Ernest Brookes. As soon as The Great War was broadcast, David Laing, a driver who served in the RASC. Motor Transport between May 1915 and May 1919, wrote to Essex that he had been the driver and orderly to the War Office official cinematographers Lieutenant Geoffrey Malins and Lieutenant Brookes. Laing wrote:

On the introduction of each week's series you have a still picture of a soldier standing by a cross on a war grave, well I am almost sure this picture is of myself, as I well remember Lieutenant Brookes asking me to pick up a rifle, (which I did not carry normally) and stand on this little mound as the sun was setting as he thought it would make a good picture. (Letter from David Laing to Tony Essex, undated) ${ }^{14}$

The image of the silhouetted soldier, taken on 22 August 1917 at Pilkem Ridge, is 'a photograph of the way the war will come to be remembered' (Dyer, 1994: 7). Taken 15 months before the Armistice, it has been 
suggested that it is 'a photograph of the future, of the future's view of the past. It is a photograph of Binyon's poem, of a sentiment. We will remember them.' Binyon's words were written in September 1914 before the British Army suffered substantial losses. His poem is 'a work not of remembrance but of anticipation, or more accurately, the anticipation of remembrance, a foreseeing that is also a determining' (Dyer, 1994: 7). These fresh pieces of documentary evidence lend weight to the assertion that the production of The Great $W$ ar was carried out in a similar spirit of commemoration and sense of historical record.

\section{Audience reception}

The first episode of The Great War was broadcast on BBC2 on the evening of 30 May 1964. The series enjoyed high audience ratings which were measured by the BBC's in-house audience research department, scoring an average reaction index of 80 out of 100 over all 26 episodes, putting it in the same league as two popular documentary series on the Second World War, War in the Air (1954) and Valiant Years (1961). ${ }^{15}$ The lone soldier's gaze appears to have exerted a great deal of power over the viewing audience in Britain during 1964-5, evident in the volumes of related correspondence sent to the BBC. However, most of the letters were written after the BBC had announced in the Radio Times in April 1965 that photographs of the staring soldier would be sent to those who wrote in to request one. This suggests that the BBC actively encouraged people to stare back at him, as an attempt to consolidate the popularity and emotional drive of the series with the face that was beamed into their living rooms at the beginning of every episode. The viewer's cultural understanding of the war as a bloody and terrible event was reinforced by the visual and emotional power of the series, and personified by the image of the staring soldier. Viewers' letters suggest that they felt compelled to meet his gaze:

If one looks deep and long into this picture - into this abyss of hell - a whole galaxy of the horrors of war are revealed. Once a quiet sort of chap really, quite content to go home to his wife and kids after a hard day's work, eyes that held nothing but love for his family. But now after being trained to kill or be killed, are eyes that seem to burn and accuse us, the eyes seem filled with shock - hatred - mistrust - disgust - despair - loneliness, and the pleading questions of why - for what - to what end - for whom. Yes, it's all there even a look of pity, like forgive them for they know not what they do ... what do we need the atom bomb for as a deterrent? When we have here a lone soldier sitting, so silent but telling us so much. (BBC WAC T32/1,145/5, Mrs G.R. Trowsdale, January 1966)

One viewer wrote that 'of all the pictures of the many thousands in this series, this single one epitomizes The Great War'. ${ }^{16}$ Another viewer wrote to say the image was 'a fitting memento to one of the most appalling incidents this century ${ }^{17}$ Age does not also appear to have mattered, as 
one viewer born in 1886 said that 'Bailey' 'so reproachfully looks at the generation of which I belong. ${ }^{18}$ The series also seemed to convey to certain viewers a great deal about a war that had cast a shadow over their childhood experiences. One woman wrote that

I have never watched any programme which has made such an impression on me - I was 12 when this war ended so I do have vague memories of it. Now that I have seen the horrors of trench warfare I can well understand why none of my uncles would ever talk about their experiences. (BBC WAC T32/1,145/1, Miss L.F. Astell to Tony Essex, 12 April 1965)

Another viewer recounted that

your series brought back to mind and memory the agony of the people whom I remember, even as a very small boy, when they received tragic news of husbands and sons. It is right that all should be reminded, or more important, taught the history with its attendant tragedies. (BBC WAC T32/1,145/1, J. Armstrong to Tony Essex, 9 December 1964)

The Great War attracted viewers from a wide range of age groups. A number of children watched the series and there are several letters from children in the BBC archives. The staring soldier was a popular subject, as one young man wrote:

I feel most awfully sorry for that man at the beginning. He is now my hero. Please could I have a picture of him to stitch in my photo album along with the rest of my friends? (BBC WAC T32/1,145/2, D.J. Ballard, 14 April 1965)

A 13-year-old wrote: 'I agree entirely with the girl who said "he means more to me than the Beatles".19 Another young viewer, who was told to watch the series by her history teacher, wrote to say that she would like a picture of the staring soldier because 'I will always be reminded of what History really means'. ${ }^{20}$ Most significantly, veterans appeared to see something familiar in 'Bailey'. One ex-field artillery officer wrote asking for a copy of the photograph, saying:

Never has his character been so ably portrayed and to me he is the live memory of all the thousands who I have known, passed and spoken [with] ... in those my young days. (BBC WAC T32/1,145/1, E. Bolton Morns, 14 May 1965)

Another former officer wrote that the image was 'a remarkable projection of what a British soldier might have been feeling like'. ${ }^{21} \mathrm{~A}$ former soldier who fought in the 1st Battalion Worcester Regiment, 8th Division in 1918 wrote that:

The choice of the man in the introduction to each programme denotes a stroke of genius ... for many years I have had a copy of C. R. W. Nevinson's 'Group of Soldiers' but always I felt he had somehow failed to portray the essential qualities of the English soldier of that time. When 'your man' first came on to the screen I knew immediately that this picture fulfilled the image. (BBC WAC T32/1,145/1, T.B. Blight to Tony Essex, 10 April 1965) 
But why did the image of the staring soldier exert such a powerful resonance with successive viewing audiences? A semiotician would underline the popular cliché that the eyes are the mirrors of the soul, and in some cultures, to give someone the 'evil eye' is to threaten or warn them in some way. The primary function of such a gaze is phatic: this mode signals verbal interaction in the initiation and maintenance of conversation to indicate that a communicative channel is open. A prolonged gaze at another person can be seen as a signal for them to speak next, and as an index of intimacy, sympathy, hostility, aggression, or dominance (Nöth, 1990). As television images are perceived in the present tense,

these figures are also ghosts or simulacra of others who have already acted out their parts ... The indexical image authenticates testimony now about what happened then. With historical footage from the time recounted appended to it, indexicality may guarantee an apparent congruity between what happened then and what is said now. (Nichols, 1994: 4)

If the staring soldier, who as 'Private Bailey' was widely believed to have died on the Somme, was taken to represent Britain's war dead, then the silhouetted soldier was the living unknown warrior - a figure representing the millions that did return.

Despite its impressive scale, importance and popularity with viewers, The Great $W$ ar did not change the way that the majority of the nation thought about the war. This is because its creator, Tony Essex, did not intend it to be so: The Great $W$ ar was his memorial to the dead of the First World War. As he admitted in a newspaper interview:

I wasn't after a mere script so much as a narrative which was substantial in its own right, something with literary value. In the end it turned out what I regard as one of the main powers of the series - the contrast between the wide-ranging and often beautiful words you heard and the concentration on the detail you saw. (Marsland Gander, 1964: 15).

Essex admitted in another newspaper interview that he was 'an emotional person' and that 'it really is about time television started to have some emotional impact. That would be a sign of its maturity' (Howarth, 1965: 8). The majority of scripts for the series were written by the military historians John Terraine and Correlli Barnett, making it the only documentary about the First World War to have been written by professional historians. The emotive power of the images and the dramatic use of music, the majority of which came from the symphonies of Shostakovich, music which Essex thought was 'highly evocative', overwhelmed the masterly script. ${ }^{22}$ However, not everyone was pleased with the series once it had been broadcast. Terraine, who went on to write the authorized on-screen biography The Life and Times of Lord Mountbatten (ITV, 1968), continued to be frustrated by the highly emotive reception that The Great $W$ ar received:

I am now sick to death of being told how good it was by people who know nothing of the subject, but were 'moved' by it, usually in directions precisely 
opposite to that I would wish. I am sure that the great reclame [sic] was due to its emotional impact, almost undefiled by celebration. Where, for example, was any analysis of the leading characters of the War, military or civil? How could there be, in that style? Where was the strategic debate? Where were the tactical innovations? Where was the war in the Air? (Barnett, 2006: 6-7)

Essex was deeply involved with all aspects of the series, and this included dealing with viewers' correspondence. He took it upon himself to reply in person to every letter he received, a task which he completed a year after the series was first broadcast. As with his design requirements for the opening titles, copies of the letters Essex sent to viewers provide us with a glimpse into his attitude to the war. A typical reply of Essex's to a viewer's letter underlined that:

I know you must at times feel that these boys died in vain, but in fact the preservation of a democratic way of life demands tremendous sacrifices, and these have certainly been made. The fact that we are not yet advanced enough to put our democratic way of life to better use (or indeed appreciate it as it should be appreciated), is another matter, but this will come with time, and the boys who died have given us more of it. We should all be thankful. (BBC WAC T32/1139/1, Tony Essex to Mrs M.C. Utton, 13 April 1965)

The fact that Britain's public service broadcast corporation poured such an enormous amount of human and financial resources into The Great War is a clear indication of the position that both the series and the war itself were thought to have held in British cultural life. The series also showed that television could serve as a repository for human memory for which, as the parallel expansion in published histories and memoirs has shown, there was a considerable market in Britain from the 1960s. In commercial terms The Great $W$ ar was a huge success for the BBC. Broadcast rights to the series were purchased by a number of other countries, and a succession of awards was bestowed upon it, such as the Screenwriters' Guild Documentary Script Award of the Year 1964 to John Terraine and Correlli Barnett, and an award from the Television Producers' Guild. The BBC capitalized on the success of the series and decided to run the programme in a prime-time BBC1 slot from October 1964 before the first broadcast run had been completed on $\mathrm{BBC} 2$ in November, a decision which took the series into the living rooms of millions more Britons. On the back of The Great $W$ ar's success, the BBC commissioned a sequel, The Lost Peace: 1918-1933, a 13-episode series about the inter-war years to be broadcast in autumn 1966. Essex was readily awarded another six-figure budget, and The Great War's principal scriptwriter/historians John Terraine and Correlli Barnett were commissioned to write the script.

\section{The Great War in the 21st century}

After The Great $W$ ar was repeated twice in the early 1970 s, the series 106 would languish in the BBC library unless an application was made to 
the $\mathrm{BBC}$ to rent a viewing theatre at Broadcasting House for the purpose of legitimate research. The Times columnist A.A. Gill fumed about the problems that he had experienced in trying to obtain a copy of The Great War in 1996, and he had to wait another six years before the series was released on VHS and DVD. Gill decided that the BBC's hidden agenda was a desire to increase the value of its library stock. As the number of channels proliferated, especially after the arrival of digital and satellite broadcasting, they expected that the demand for ready-made programmes would rise and increase the value of their archives:

A untie doesn't want to risk alienating her rich suitors by giving you or me one-night stands. But the archive is valuable in another way too; it is the single greatest repository of the defining cultural form of our century. It is like having the Vatican in a cellar or keeping Beethoven symphonies, Mozart operas and Dickens novels in a box. No, it's more than that - it's like someone coming and taking your photograph album and saying you can't see it because somebody else wants to buy it. (Gill, 1996: 9-10)

Gill had wanted to get a copy of The Great War after watching the American-made seven-part documentary 1914-18 (KCET/BBC 1996), which was broadcast in the US as The Great $W$ ar and the Shaping of the 20th Century. The series, billed as the 21st-century's answer to The Great War, took seven years and \$6 million to make (Winter and Baggett, 1996). While The Great $W$ ar had striven to produce a developing philosophy on war and to give an account of the political, social and economic history of the 20th century, the cultural bias of 1914-18, for example the series? overemphasis on war poetry, drew unfavourable comparisons with The Great War, and the majority of historians and television critics were united in their preference for the epic of 1964.

The pre-eminence of The Great $W$ ar was again underlined with the broadcast of The Trench (BBC, 2002), the first programme about the First World War to be made in the reality-reconstruction documentary genre. The Trench was a three-part series which followed 24 male volunteers from Hull who 're-experienced' elements of what their forebears had encountered in the 10th Battalion East Yorkshire Regiment (the 'Hull Pals') in the trenches of 1916. The progressive nature of the series provoked considerable media outrage long before it was due to go into production. Because it was wholly different to the narrative approach of other documentaries about the First World War, including The Great War, The Trench was pilloried as Big Brother in the trenches. One television critic cynically suggested a similar format based in Auschwitz (Lawson, 2002). Only one journalist conceded that, although nobody was firing live ammunition in The Trench, no one was dropping bombs on the inhabitants of Channel 4's 1940's House either (Henscher, 2002). Nevertheless, few commentators recognized that it was made to bring to life the practicalities and some of the basic everyday realities of trench warfare in 1916, details that experts 
should not assume are widely known to a viewing public raised on war poetry and novels. The Trench was not intended to give viewers yet another grand narrative about the origins of the First World War because The Great War still stands as the widely accepted authority on the subject. Alternatively, by showing viewers what the men who fought for king and country in the First World War endured for their benefit on a day-to-day basis, The Trench was a televisual memorial in a 21st century format.

The Great War was released on VHS and DVD in 2002, and the BBC announced that the series was to be shown on $\mathrm{BBC} 2$ and the satellite/digital terrestrial channel BBC Four in the following year. The BBC described the series as 'the definitive film account of the world-shattering events of 1914-1918'. They were keen to underline that it was reshowing 'a documentary masterpiece', perhaps in anticipation of two major series scheduled for broadcast in summer 2003: Channel Five's World War One in Colour and Channel 4's The First World War. The Great War was welcomed back in a wave of nostalgia. The series was generally acknowledged to have withstood the test of time and was lauded for its 'clarity, the intelligence of the script and the lack of histrionics' (Hoggart, 2003: 19). An introductory documentary - That Was The Great War That Was - was also broadcast on 22 February 2003, featuring interviews with some of the series' production team. The publicity for the hour-long film, a prelude to the first episode, described how hard it was to make 'a suitable monument to such a traumatic period in history' (Rackham, 2003: 64; emphasis added).

As Britain's memory of the First World War is still understood as a national trauma, the majority of television documentaries about the conflict have been constructed and understood as sites of memory and mourning. In contemporary Britain, the act of producing and watching television programmes about the First World War is a remembrance ritual in its own right: documentaries about 1914-18 are memorials in moving images which are made for a post-literate age. Like memorials cast in stone and bronze, they attempt to ensure that society will never forget the price paid by those who fought for king and country. Despite the production of numerous other programmes, The Great War still stands as British television's original and most influential small screen memorial to the nation's experience of the First World War.

\section{Notes}

1. BBC WAC audience figures compiled by Gwyniver Jones for Professor Alex Danchev, 15 June 1988.

2. BBC WAC T32/1158/1, Donald Baverstock to Stuart Hood, 25 May 1961.

3. BBC Written Archives Centre T32/1158/1, Vera Brittain to Grace Wyndham Goldie, 18 February 1963.

4. As a direct result of The Great War series, testimonies not available to the 108 public in any quantity before the 1960 s are still available at the Imperial 
War Museum. The Museum's Sound Archive has in its catalogue 275 interviews recorded for The Great War 1963-4 and many of them can be downloaded as audio extracts from the Museum's website.

5. Edmund Blunden travelled to London for the series, but when eyewitness researcher Julia Cave saw how reluctant he was to be filmed, she sent him home, much to the annoyance of Gordon Watkins. Interview with Julia Cave, 2 March 2004.

6. Interview with Julia Cave, 2 March 2004.

7. BBC WAC T32/1152/1, Gordon Watkins to Tony Essex after a meeting with Donald Baverstock, 29 January 1964.

8. Personal communication with Anne Dacre, 8 March 2004.

9. Personal communication with Dr Jean Moorcroft, 26 February 2004. At the time Sassoon was seriously ill with a duodenal ulcer, and was later diagnosed with inoperable abdominal cancer. He died on 1 September 1967.

10. Interview with Correlli Barnett, 9 March 2004.

11. BBC WAC T32/1145/1, Tony Essex to Mrs G.H. Baker, 23 November 1964.

12. BBC WAC T32/1139/1, Tony Essex to Mrs M.E. Butterworth, 2 February 1965.

13. BBC WAC T32/1145/1, Thomas Ball to BBC, 10 A pril 1965.

14. This letter must be contemporary to the series' first run on BBC 2 from mid-1964. I am very grateful to Dr Ulf Schmidt and Roger Smither for sending me a copy.

15. BBC WAC T32/823/1-VR/64/308, Audience Research Department, 13 July 1964; Valiant Years (1961) scored an average of 80 over 26 episodes, and $W$ ar in the Air (1954) averaged 81 over 15 episodes.

16. BBC WAC T32/1145/2, Joan Gardner, 7 April 1965.

17. BBC WAC T32/1145/2, Kenneth Beale, 2 May 1965.

18. BBC WAC T32/1145/2, Herbert S. Binyon, 12 April 1965.

19. BBC WAC T32/1145/2, A.J. Close, 8 April 1965.

20. BBC WAC T32/1145/2, Margaret Ford, 2 April 1965.

21. BBC WAC T32/1145/1, Brigadier M.S. Bendle, 7 April 1965.

22. Personal communication with Anne Dacre, 8 March 2004.

\section{References}

Badsey, S. (2002) 'The Great War Since the Great War', Historical Journal of Film, Radio and Television 22(1): 37-45.

Barnett, C. (2006) 'John Terraine and Television History', Stand To! 75(January): 5-8.

Blunden, E. (1928) Undertones of War. London: Cobden-Sanderson.

Bond, B. (2002) The Unquiet Western Front. Cambridge: Cambridge University Press.

Brown, M. (2003) 'Changing the Face of War', BBC History Magazine (March): 43.

Burgess, A. (1962) The Wanting Seed. London: Heinemann.

Cannadine, D. (ed.) (2004) History and the Media. London: Palgrave

Macmillan.

Carrington, C. (1929) A Subaltern's War. London: Peter Davis. 
Carrington, C. (1965) Soldier from the Wars Returning. London: Hutchinson.

Clark, A. (1961) The Donkeys: A Study of the Western Front in 1916. London: Hutchinson.

Danchev, A. (1991) "Bunking and Debunking": The Controversies of the 1960 s', in B. Bond (ed.) The First World War and British Military History, pp. 263-88. Oxford: Clarendon.

Dayan, D. and E. Katz (1992) Media Events: The Live Broadcasting of History. Cambridge, MA: Harvard University Press.

Durkheim, E. (1965[1912]) The Elementary Forms of the Religious Life (trans. J. Ward Swain). New York: Free Press.

Dyer, G. (1994) The Missing of the Somme. London: Penguin.

Essex, T. (1965) 'Postscript to The Great War', Radio Times (1 April): 51.

Fussell, P. (1975) The Great War and Modern Memory. Oxford: Oxford University Press.

Gill, A.A. (1996) 'Oh What a Luvvie War', Sunday Times (17 Nov.): 9.

Graves, R. (1929) Goodbye to All That. London: Cape.

Gruner, T. (1964) 'BBC's "The Great War" Is a Front-Line Property', Kine Weekly (4. June): 18.

Halbwachs, M. (1980[1950]) The Collective Memory. New York: Harper and Row.

Henscher, P. (2002) 'They've Gone Over the Top in Astonishing Bad Taste', Independent (15 March): 5 .

Hoggart, P. (2003) 'Leading from the Front', The Times 'Play' (22 Feb.): 19. Howarth, J.D.S. (1965) 'Producing The Great War', Guardian (11 Feb.): 8.

Hynes, S. (1990) $A W$ ar Imagined. London: Bodley Head.

Isaacs, J. (2003) ' 24 Shows that Changed the Face of TV', Radio Times (15-21 Feb.): 16 .

Kavanagh, G. (1994) Museums and the First World War: A Social History. Leicester: Leicester University Press.

Lawson, M. (2002) 'The Battle for Ratings', Guardian G2 (11 March): 13.

Lewis, C. (1936) Sagittarius Rising. London: Peter Davis.

McArthur, C. (1978) Television and History. London: British Film Institute.

Manning, F. (1930) Her Privates We. London: Peter Davis.

Marsland Gander, L. (1964) 'The Great W ar: History on the Small Screen', Daily Telegraph (30 Nov.): 15.

Marwick, A. (2001) The New Nature of History. Basingstoke: Palgrave.

Nichols, B. (1994) Blurred Boundaries: Questions of Meaning. Bloomington:

Indiana University Press.

Nöth, W. (1990) Handbook of Semiotics. Bloomington: Indiana University Press.

Rackham, J. (2003) 'That Was the Great War That Was/ The Great War', Radio Times (22 Feb.): 64 .

Ramsden, R. (2002) 'The Great War: The Making of the Series', Historical Journal of Film, Radio and Television 22(1): 7-18.

Reimann, A. (1998) 'Popular Culture and the Reconstruction of British Identity', in H. Berghoff and R. Friedeburg (eds) Change and Inertia: Britain under the Impact of the Great War, pp. 99-120. Bodenheim: Philo.

Robb, G. (2002) British Culture and the First World War. Basingstoke: 
Sassoon, S. (1928) Memoirs of a Fox-Hunting Man. London: Faber \& Gwyer. Smith, M. (1995) 'The War and British Culture', in S. Constantine, M. Kirby and M. Rose (eds) The First World War in British History, pp. 168-83.

London: Arnold.

Sorlin, P. (1994) Mass Media: Key Ideas. London: Routledge.

Sorlin, P. (1999) 'Cinema and the Memory of the Great War', in M. Paris (ed.)

The First World War and Popular Cinema, pp. 5-26. Edinburgh: Edinburgh

University Press.

Stibbe, M. (2001) German Anglophobia and the Great War, 1914-1918.

Cambridge: Cambridge University Press.

Taylor, A.J.P. (1963) The First World War - An Illustrated History. London: Penguin.

Todman, D. (2002) 'The Reception of The Great War in the 1960s', Historical Journal of Film, Radio and Television 22(1): 29-36.

Todman, D. (2005) The Great War: Myth and Memory. London: Hambledon. Tosh, J. (2006) The Pursuit of History (4th edn). Harlow: Pearson Longman. Tuchman, Barbara (1962) The Guns of August. London: Constable.

Verhey, J. (2000) The Spirit of 1914: Militarism, Myth and Mobilization in Germany. Cambridge: Cambridge University Press.

Wiggin, M. (1964) 'Something to Be Smug About', Sunday Times (31 May): 32.

Williamson, H. (1951-69) Chronicle of Ancient Sunlight (15 vols). London: Macdonald.

Winter, J. (1995) Sites of Memory, Sites of Mourning. Cambridge: Cambridge University Press.

Winter, J. and B. Baggett (1996) The Great $W$ ar and the Shaping of the 20th Century. London: BBC Books.

Winter, J. and A. Prost (2005) The Great War in History: Debates and Controversies, 1914 to the Present. Cambridge: Cambridge University Press.

Winter, J. and J.-L. Robert (1997) Capital Cities at War: Paris, London, Berlin 1914-1919. Cambridge: Cambridge University Press.

\section{Biographical note}

Emma Hanna is a postdoctoral research fellow at the University of Greenwich, London. She was recently awarded her $\mathrm{PhD}$ by the University of Kent for her thesis 'The Great War on the Small Screen: A Cultural History of the First World War on British Television, 1964-2005'. A DDREss: University of Greenwich, Old Royal Naval College, Park Row, London SE10 9LS, UK. [email: me44@gre.ac.uk] 